\title{
PRESENT STATUS OF STRAWBERRY FRUIT ROT DISEASES IN NEW ZEALAND
}

\author{
O.E. TIMUDO-TORREVILLA ${ }^{1}$, K.R. EVERETT ${ }^{1}$, N.W. WAIPARA ${ }^{2}$, \\ K.S.H. BOYD-WILSON ${ }^{3}$, P. WEEDS ${ }^{2}$, G.I. LANGFORD ${ }^{3}$ \\ and M. WALTER ${ }^{3}$
}

${ }^{1}$ HortResearch, Private Bag 92169, Auckland, New Zealand

${ }^{2}$ Landcare Research New Zealand Ltd, Private Bag 92170, Auckland, New Zealand

${ }^{3}$ HortResearch, PO Box 51, Lincoln, New Zealand

Corresponding author: mwalter@hortresearch.co.nz.

\begin{abstract}
The New Zealand strawberry industry experiences losses due to fungal diseases that can cost up to $\$ 4.4$ million per annum or $20 \%$ of the crop value. Disease control relies almost exclusively on applications of the fungicide captan. During the 2003/2004 production season, grower monitoring trials investigated the relative importance of grey mould (Botrytis cinerea), anthracnose (Colletotrichum acutatum) and leak (Rhizopus spp.) in causing postharvest fruit rot. The average fruit rot incidence (expressed per day) was 3.6, 2.2 and 1.6\% for grey mould, leak and anthracnose, respectively, when ripe fruit was incubated at room temperature under high humidity. In two grower trials and one replicated spray trial, frequent captan applications did not reduce grey mould, anthracnose or leak incidence compared to an unsprayed treatment. Integrated management strategies for control of strawberry fruit rot diseases are urgently required for New Zealand strawberry growers.
\end{abstract}

Keywords: captan, Botrytis cinerea, Colletotrichum acutatum, Rhizopus spp.

\section{INTRODUCTION}

Strawberry (Fragaria ananasa) is the largest export berry fruit industry in New Zealand with an estimated value of NZ\$22 million per annum, and strawberry production comprises $47.6 \%$ of the total berry fruit production. The Auckland region produces over $40 \%$ of the commercial crop, but strawberries are also grown in other regions within New Zealand, such as Waikato, Hawke's Bay, Horowhenua and Canterbury (Strawberry Growers New Zealand Inc. (SGNZ), pers. comm.). Production volumes vary depending on the selected variety, district, weather conditions, crop management, and pest and disease management. The industry experiences losses due to fungal diseases that can cost up to $\$ 4.4$ million per annum (SGNZ, pers. comm.). Soil fumigation, multiple aerial plant/fruit spraying and plastic wrap mulching have been implemented and are required to manage fungal disease to economically viable levels. Very little research has been done in New Zealand to address sustainability of strawberry fruit production by reducing fungicide use.

The most important strawberry fruit rot problems in New Zealand are grey mould caused by Botrytis cinerea, anthracnose primarily caused by Colletotrichum acutatum, and strawberry leak generally caused by Rhizopus spp. However, in New Zealand there are no data that compare the relative importance of these pathogens in commercial strawberry production. Detailed accounts of fungal diseases in strawberry are given in Maas (1998), but brief descriptions of grey mould, anthracnose and leak are given below. 
Botrytis cinerea is a fungal disease that infects a wide range of annual and perennial plants. Infection is favoured by cool, rainy weather usually around $15-23^{\circ} \mathrm{C}$. The infection starts when flowers open and symptoms are visible after the fruit begins to ripen. The pathogen generally causes large, brown lesions, typically at the stem ends of the fruit. In the presence of free water the fungus then sporulates covering entire fruit with a grey mass of conidia and conidiophores (Legard et al. 1997). The most important symptom of grey mould is early infections causing small, mummified fruit (Maas 1998). In Florida, grey mould is responsible for fruit losses as high as $35 \%$ in untreated plots (Legard et al. 1997). Fungicide sprays applied during flowering and fruiting are the chief control measure against grey mould fruit rot (Maas 1998). In New Zealand, fungicide control is based upon frequent captan, thiram and most recently fenhexamid (Teldor ${ }^{\circledR}$ ) applications (SGNZ, pers. comm.).

Anthracnose is an important disease affecting a wide range of crops, including strawberries around the world. It can cause postharvest fruit rots in avocado (Persea americana), bitter rot on fruit before harvest in apple (Malus $x$ domestica), and terminal crook on young seedlings of Pinus radiata (Hartill 1992; Pennycook 1989). In strawberries, the symptoms can be present on leaves, petioles and fruits and are characterized by small dark and sunken lesions on green fruit which develop into hard lesions covered by abundant orange masses of conidia in a mucilaginous matrix on ripe fruit (Maas 1998). Infection by $C$. acutatum can occur on nursery plantings and the disease can then be spread on plants from the nursery to the field (Freeman 2004). For control, it is recommended to obtain strawberry transplants from pathogen free nurseries, to dispose of infected material from the field, and to plant resistant cultivars (Mertely \& Peres 2005). The pathogen may be present in the field as symptomless latent infections which then express after harvest (Sinclair 1991). Anthracnose may be partially controlled by applying protective fungicides from flower bud emergence through to harvest (Maas 1998). However, most fungicides have limited efficacy against anthracnose, resulting in unsatisfactory control (Maas 1998). In New Zealand, anthracnose control is based predominantly on captan applications (SGNZ, pers. comm.).

Leak is considered to be a common postharvest or storage rot, but can occur in ripe fruit in the field. The causal organisms are Rhizopus stolonifer, R. nigricans or occasionally $R$. sexualis (Maas 1998). Cunningham (1922) first reported leak in ripe strawberry fruit in New Zealand. The disease is characterised by a soft and watery rot resulting in a quick collapse and juice leakage of entire fruit. Adjacent fruit can become infected by spreading mycelia or from contaminated juice. Under hot and dry or overwintering conditions Rhizopus spp. can survive for long periods as zygospores and for several months as sporangiospores on plant debris and in the soil (Maas 1998). Rhizopus spp. infect only through wounds (Maas 1998). Infection and disease development are controlled postharvest by rapid cooling and maintenance of storage temperatures below $6^{\circ} \mathrm{C}$. Fungicide options for leak control include thiram and captan and more recently cyprodinil + fludioxonil $\left(\right.$ Switch $\left.^{\circledR}\right)$ applications (Kaufman 2000). In New Zealand, leak control is not specifically managed (SGNZ, pers. comm.).

In summary, captan is the most important fungicide for grey mould and anthracnose control for strawberry production in New Zealand. It is applied at 5-10 day intervals during the flowering and fruiting season (SGNZ, pers. comm.). The aims of this study were primarily to determine the relative importance of grey mould, anthracnose and leak under commercial production systems in New Zealand and to investigate the efficacy of captan to control these pathogens.

\section{Grower monitoring}

\section{MATERIALS AND METHODS}

In the 2004/2005 strawberry production season, incidence of grey mould, anthracnose and leak was monitored on four grower properties in the Auckland area (Rodney District and Kumeu). The fungicide spray regimes applied on these properties are presented in Table 1. Two of the four growers (Growers 2 and 3) allowed for at least two unsprayed 
rows within the same block. Ripe ( $>90 \%$ red) strawberries were picked from the commercial gardens at 7-day intervals during the main fruiting season (November/ December) for 5 weeks from four randomly chosen plots in each commercial block (cultivars Camerosa or Gaviota) for each sprayed and unsprayed row. A plot consisted of 12 plants. The fruit sample consisted of all ripe berries within the plot. Berries were picked into individual compartments of new kiwifruit plix-trays, then incubated at room temperature $\left(21 \pm 3^{\circ} \mathrm{C}\right)$ under high humidity for $4-8$ days, and incidence of grey mould, anthracnose or leak was determined by visual inspection.

TABLE 1: Agrichemical spray dairies (flowering and fruiting period 2004) for the four grower properties monitored for strawberry fruit rot incidence.

\begin{tabular}{lllll}
\hline Period & Grower $^{1}$ & Grower $2^{1,2}$ & Grower $3^{1,2}$ & Grower $^{1}$ \\
\hline 30 Aug-5 Sep & Nil & Captan & Nil & Captan \\
6 Sep-12 Sep & Nil & Nil & Nil & Captan \\
13 Sep-19 Sep & Chlorothalonil & Nil & Nil & Nil \\
20 Sep-26 Sep & Chlorothalonil & Captan & Captan & Captan \\
27 Sep-3 Oct & Captan & Captan & Captan & Captan \\
4 Oct-10 Oct & Captan & Captan & Captan & Captan \\
11 Oct-17 Oct & Captan & Captan & Captan & Captan \\
& Fenhexamid & & & \\
18 Oct-24 Oct & Captan & Captan & Captan & Captan \\
25 Oct-31 Oct & Captan & Captan & Nil & Nil \\
1 Nov-7 Nov & Captan & Captan & Captan & Captan \\
8 Nov-14 Nov & Captan & Captan & Nil & Captan \\
15 Nov-21 Nov & Captan & Captan & Captan & Nil \\
22 Nov-28 Nov & Captan & Nil & Nil & Nil \\
29 Nov-5 Dec & Captan & Fenhexamid & Nil & Nil \\
\hline Total & 13 & 11 & 7 & 9 \\
\hline
\end{tabular}

${ }^{1}$ Captan (Orthocide 80 WDG, Elliott Technologies Ltd; Grower 1=1 kg/ha, Grower $2=2.2 \mathrm{~kg} / \mathrm{ha}$, Grower $3=3 \mathrm{~kg} / \mathrm{ha}$, Grower $4=1.2 \mathrm{~kg} / \mathrm{ha}$ ); chlorothalonil (Bravo $720 \mathrm{SC}$, Yates New Zealand Ltd, 2 litres/ha); fenhexamid (Teldor ${ }^{\circledR}$, Bayer New Zealand Ltd; 1.5 litres/ha). Fungicides were applied using grower equipment according to manufacturers' instructions.

${ }^{2}$ These growers had at least two unsprayed rows within the block.

${ }^{3}$ First fruit pick in this week.

\section{Spray trial}

A replicated spray trial was conducted in Auckland (Kumeu) on a commercial property (Grower 2) comparing treatments of captan (CaptanFlo, Nufarm), with three undisclosed Trichoderma-based biological control agents (BCA, referred to as BCA-R, BCA-S and BCA-T) and an unsprayed (or nil) experimental control. Products were applied according to the manufacturers' recommendation using a knapsack sprayer, applying chemical to just before run-off or approximately $83 \mathrm{ml} / \mathrm{plant}$. There were five (7 day interval) applications of each treatment, starting on 29 September 2004. A replicate plot consisted of 12 plants, cultivar Gaviota. Plots were arranged at random across four rows, with four replicate plots per treatment. All ripe fruit (>90\% red) in a plot were picked in weekly intervals for 7 weeks. The first fruit pick was on 29 October 2004. Berries were picked into the individual compartments of new kiwifruit plix-trays, then incubated at room temperature $\left(21 \pm 3^{\circ} \mathrm{C}\right)$ under high humidity for 4-8 days, and incidence of grey mould, anthracnose or leak was determined as above. 


\section{Statistical analyses}

Disease incidence data were transformed to incidence rot/day by dividing incidence data by the number of days of incubation to facilitate pooling of data for all harvests and incubation times. Univariate analysis of variance (ANOVA) and Fisher's least significant difference test (LSD, $\mathrm{P}=0.05)$ were then used to determine treatment effects and treatment differences, respectively, separately for each disease. The software Systat 11 (Systat Software Inc, Richmond, California, USA) was used.

\section{RESULTS}

In the grower monitoring trial, there was no difference $(\mathrm{P}>0.05)$ between the two cultivars for incidence of grey mould, anthracnose or leak. Therefore data was pooled across cultivars. For Growers 2 and 3, there was no significant difference $(\mathrm{P}>0.05)$ in disease incidence (grey mould, anthracnose and leak) between sprayed and unsprayed fruit (Fig. 1). The grower monitoring data showed that in the fungicide treated rows incidence of grey mould, anthracnose and leak varied $(\mathrm{P}>0.05)$ among the growers (Fig. 1).

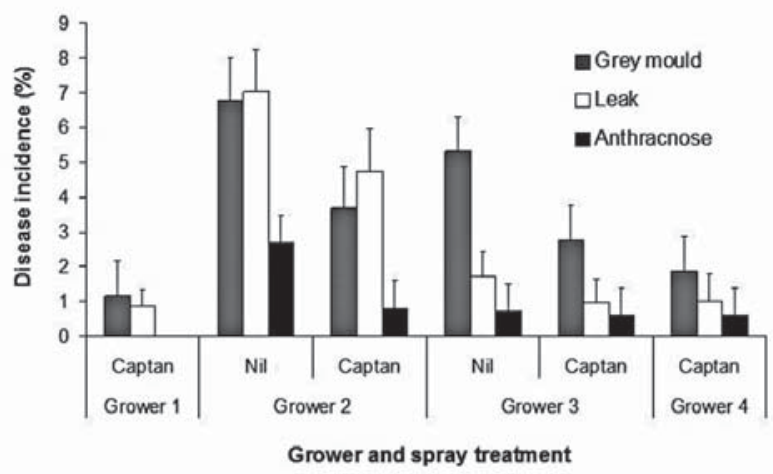

FIGURE 1: Disease incidence (\% per day incubation) for grey mould, leak and anthracnose from strawberries sprayed with the fungicide captan or left untreated (nil), and harvested during November/December 2004 at weekly intervals for 5 weeks from four grower properties. Bars represent the standard deviation of the means. Corresponding fungicide spray applications are outlined in Table 1.

In the spray trial, neither captan nor the BCA treatments reduced $(\mathrm{P}>0.05)$ disease incidence (grey mould, anthracnose and leak) compared to the unsprayed treatment, except for some reduction $(\mathrm{P}<0.05)$ in leak incidence with BCA-S (Fig. 2). It is noteworthy that for fruit treated with the Trichoderma-based BCAs, and not for any other treatments, fruit rot due to Trichoderma spp. was observed (data not shown).

Combining grower and spray trial data, the average fruit rot incidence per day incubation was 3.6, 2.2 and 1.6\% for grey mould, leak and anthracnose, respectively.

\section{DISCUSSION}

These preliminary grower investigations on the relative importance of the three fruit rot pathogens (grey mould, anthracnose and leak) in commercial strawberry production suggests that fruit infection and postharvest storage rot can be caused by these diseases, 
each at similar levels of incidence. These findings were confirmed in the spray trial. Similar fruit rot levels for grey mould, anthracnose and leak were also found in a field trial evaluating commercially available biological control agents for grey mould control (M. Walter, unpubl. data).

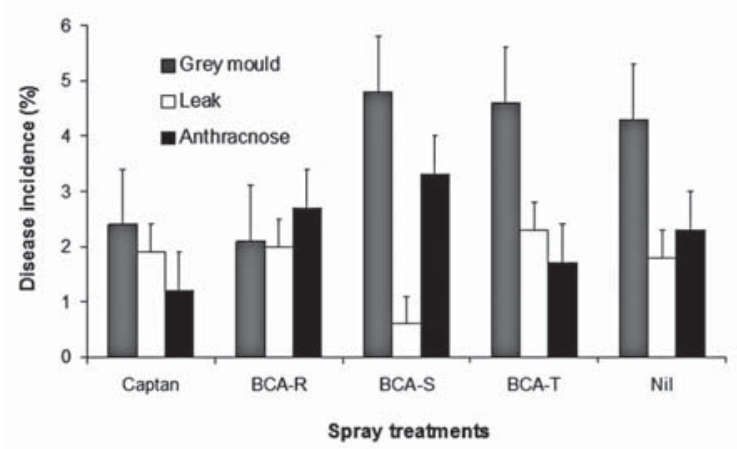

FIGURE 2: Disease incidence (\% per day incubation) for grey mould, leak and anthracnose in a replicated fungicide trial comparing captan with three Trichoderma based biological control agents (BCA-R, BCA-S, BCA-T) and an unsprayed treatment (nil). Bars represent the standard deviation of the means.

Captan, the most commonly used product for strawberry disease management in New Zealand, has not shown high efficacy in controlling fruit rots (grey mould, anthracnose and leak) compared to an unsprayed treatment on the commercial properties of Grower 2 and Grower 3, as well as in the spray trial. While disease levels were reduced when spraying predominantly captan (Figs $1 \& 2$ ), the differences were not statistically significant compared to the unsprayed treatment. This is despite numerous fungicide applications at 5-10 day intervals (Table 1). The growers monitored in this study used between seven and 13 fungicide applications over the main production season. Additional unpublished research confirms that captan may not be controlling strawberry fruit diseases. While this lack of captan efficacy could be a seasonal effect due to the unusual cold, wet spring and early summer during 2004, it nonetheless raises concerns with regard to captan efficacy for control of grey mould and anthracnose. The similarity in disease levels between sprayed and unsprayed treatments also suggests that the number of fungicide applications in New Zealand strawberry production could be reduced. Integrated management strategies to improve control of strawberry fruit rot diseases and to develop sustainable production systems are urgently required for New Zealand strawberry growers.

\section{ACKNOWLEDGEMENTS}

This research was conducted as part of a larger project on "Sustainable Disease Management and Control of Strawberry Fruit Rot in New Zealand" funded by Strawberry Growers New Zealand Inc. and the Ministry of Agriculture and Forestry (MAF) with the allocation from the Sustainable Farming Fund (SFF). Dr Chris Frampton assisted with statistical advice and analyses. 


\section{REFERENCES}

Cunningham GH 1922. Some recent changes in the names of plant-diseases. Part II. Diseases of small-fruits. Part III. Diseases of vegetables. New Zealand Journal of Agriculture 24: 37-45.

Freeman S, Minz D, Kolesnik I, Barbul O, Zveibil A, Maymon M, Nitzani Y, Kirshner B, Rav-David D, Bilu A, Dag A, Shafir S, Elad Y 2004. Trichoderma biocontrol of Colletotrichum acutatum and Botrytis cinerea and survival in strawberry. European Journal of Plant Pathology 110:361-370.

Hartill WFT 1992. Post-harvest rots of avocados in New Zealand and their control. Proceedings of the Brighton Crop Protection Conference - Pests and Diseases: 1157-1162.

Kaufman D 2000. Oregon strawberry newsletter. Oregon State University, North Willamete Research \& Extension Center, USA. 6 pp.

Legard DE, Widden AJ, Chandler CK 1997. Incidence and occurrence of strawberry diseases in Florida from 1991-1996. Advances in Strawberry Research 16:35-47.

Maas JL 1998. Compendium of strawberry diseases. 2nd ed. APS Press, St Paul. 98 pp.

Mertely JC, Peres NA 2005. Anthracnose fruit rot of strawberry. Plant Pathology Department, Florida Cooperative Extension Service, Institute of Food and Agricultural Sciences, University of Florida. Document PP-207. 6 pp.

Pennycook SR 1989. Plant diseases recorded in New Zealand. Part 2: Plant Diseases Division, DSIR, Auckland. 501 pp.

Sinclair JB 1991. Latent infection of soybean plants and seeds by fungi. Plant Disease 75: $220-224$. 